\title{
THE MAXIMUM WARMINGS OF THE PLEISTOCENE WORLD CLIMATE RECORDED IN THE CANARY ISLANDS
}

\author{
Meco, J. ${ }^{\text {, }}$ Guillou, H.b, Carracedo, J.-C. ${ }^{c}$, Lomoschitz, A. ${ }^{\text {d }}$, Ramos, A.-J.G. ${ }^{\text {, }}$ \\ Rodríguez-Yánez, J.-J. ${ }^{\mathrm{a}}$
}

\footnotetext{
a Departamento De Biología, Universidad De Las Palmas De Gran Canaria, Campus Universitario De Tafira, E-35017 Las Palmas, Canary Islands, Spain

b Laboratoire Des Sciences Du Climat Et De l'Environnement, Unité Mixte De Recherche CNRS-CEA, Bât. 12, Avenue de la Terrasse, F-91198 Gif-sur-Yvette, France

c Estación Volcanológica De Canarias, IPNA-CSIC, Aptdo. Correos 195, Tenerife, Canary Islands, Spain

d Departamento De Ingeniería Civil, Universidad De Las Palmas De Gran Canaria, Campus Universitario De Tafira, E-35017 Las

Palmas, Canary Islands, Spain
}

\begin{abstract}
Evidence of the warmest Pleistocene climatic changes is preserved in the eastern Canary Islands. Although the existence of raised fossiliferous marine deposits in northern Gran Canaria has been known since the 19th century, their chronology and significance with regard to past sea levels and temperatures have remained uncertain. Here, we show three marine transgressions recorded by raised marine deposits. The highest ( $85 \mathrm{~m}$ above sea level (masl)) and oldest marine deposit is interbedded in basaltic lava flows and has been dated using both palaeomagnetic and radiometric methods. The age of these deposits, located on the northwest coast of Gran Canaria, near the town of Agaete, places the marine transgression in a first Pleistocene interglacial into the Plio-Pleistocene limit. The marine deposit at an intermediate altitude (35 masl) has been dated using the unspiked K-Ar method on a pillowed basaltic lava flow. The age of these deposits in Arucas places the transgression in the penultimate (European Mindel/Riss sense) interglacial. The deposits at 12 masl in Las Palmas are attributed to the last Pleistocene interglacial on the basis of their fossil content, which is similar to that of the Matagorda deposits in Lanzarote and Matas Blancas in Fuerteventura. Radiometric dating of a lava flow overlying similar deposits at El Cotillo in Fuerteventura has been carried out. The molluscan fauna associated with the deposits permits an estimation of the sea temperatures by reference to their present biogeographical distributions. The Plio-Pleistocene boundary coincides at Agaete (end of Olduvai event) with a high sea level between 1.8 and $1.75 \mathrm{Ma}$ (oxygen isotopic stage (OIS) 63), the dated marine deposits at Arucas (0.42 Ma) place an interglacial in OIS 11.3 and finally we confirm that, in the Canaries, with only one high sea level with a Senegalese fauna (OIS 5.5), they are not an outpost for the Mediterranean Tyrrhenian (deposits with Strombus) oscillations.
\end{abstract}

